\title{
Protection of geological heritage: A North American perspective on Geoparks
}

\author{
1 Geological Survey of Canada, 3303 -33rd Street N.W., Calgary, Alberta, Canada T2L 2A7 \\ 2 Geological Survey of Canada, 601 Booth Street, Ottawa, Ontario, Canada K1A 0E8 \\ 3 Department of Earth Sciences, Simon Fraser University, Burnaby, British Columbia, Canada V5A 1S6
}

\begin{abstract}
The First International Conference on Geoparks was held in Beijing, China in June 2004. At that conference we were immersed in the UNESCO concept of Geoparks for the first time. As North Americans, we take for granted national, provincial and state parks, which are scattered throughout the continent and provide recreational and educational opportunities. The concept of parks is a long standing one in North America, whereas the UNESCO concept of geoparks is relatively new. In this paper we compare the two kinds of parks and explore the value of both as sites of geoscience experience and education.
\end{abstract}

\section{North American parks}

Parks have been an integral part of North American life for more than a hundred years. The first national park in the United States, Yellowstone National Park, was established in March 1872 (Figure 1). This marked the first occasion when public lands were set aside and administered by the government for the purpose of preservation, recreation and education. The Government of Canada likewise has set aside national parks and national park reserves for a variety of special purposes, including recreational use and preservation of wilderness. In 1885, it established the first national park, at Banff, Alberta.

Today there are 387 entities in the U.S. National Park system, totalling 331,842 square kilometres or $3.5 \%$ of the total land area of the United States. In addition, there are 5655 state park areas totalling 52,609 square kilometres. Together, these parks represent $4.1 \%$ of the land area of the United States.

In Canada, national parks continued to be established steadily until the late 1930s. During the 30 years from 1937 to 1967, only two new parks were established, but 10 national parks were established from 1968 to 1972 and new parks have been added regularly since the late 1970s. Each park is an area of outstanding scenic beauty, a locality of historical importance or a site containing unique features. These interests are often combined in designating a park. The 42 Canadian national parks range in size from 8.7 square kilometres to 44,807 square kilometres and collectively cover an area of 224,466 square kilometres or $2.2 \%$ of the total area of Canada. In addition, there are 2716 provincial parks. Some parts of Canada have more than $10 \%$ of the land assigned to parks, recreation areas and ecological reserves. For example, $11.8 \%$ of British Columbia is protected in 817 different parks and about $10.5 \%$ of Alberta is protected in more than 500 provincial and national parks.

Not all of these national parks can be considered strictly as geoparks, but many have geological features as their central, important feature. Many of the key national parks in the United States also have geoscience at their core, for example the original Yellowstone National Park and the famous parks in Utah. In Canada, the most

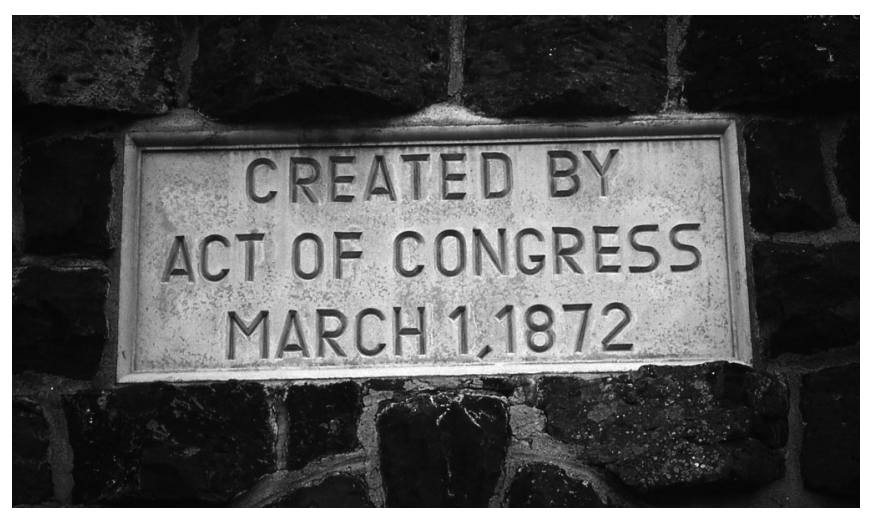

Figure 1 Memorial plaque at Yellowstone National Park commemorating the founding of the first North American national park (photo courtesy U.S. National Parks Service).

obvious example is the World Heritage Site comprising the Rocky Mountain national parks. The mountains themselves form the central theme of these parks, and many of the interpretive sites within the parks deal with geological history. These magnificent mountains are composed mainly of Paleozoic carbonates thrust over Mesozoic rocks (Figure 2). The mountains were repeatedly glaciated during the Pleistocene, creating a landscape that attracts great interest and serves as a wonderful natural laboratory for explaining the process of mountain building and erosion. These parks were recognized as a World Heritage Site in 1984 and include Yoho National Park, the type locality of the world famous Burgess Shale which is a World Heritage Site in its own right.

Another excellent example of a North American park with strong geoscience values is Gros Morne National Park in western Newfoundland. There the spectacular limestone breccias of the Cambro-Ordovician Cow Head Group mark the edge of Laurentia, where oceanic crust from the Iapetus Ocean was thrust onto the ancient continent and preserved as spectacular tablelands floored by peridotite from the upper mantle. The landscape was moulded by Pleistocene ice, resulting in magnificent raised fiords such as Western Brook Pond, with cliffs that rise $650 \mathrm{~m}$ from the water and extend $165 \mathrm{~m}$ down to the floor of the lake (Figure 3). The park includes the Global Stratotype Section and Point for the base of the Ordovician System at Green Point.

Other Canadian parks focus on paleontology, for example Miguasha and Mingan Archipelago parks in Quebec and the aptly named Dinosaur Provincial Park in Alberta. Miguasha Park is considered to be the world's most outstanding site for Devonian fish fossils, which are abundantly and superbly preserved in the Upper Devonian Escuminac Formation. The rocks contain representatives of five of the six fossil fish groups associated with this period. Of particular note are beautifully preserved specimens of the lobefinned fishes that gave rise to the tetrapods, the first four-legged, airbreathing terrestrial vertebrates. The Mingan Archipelago preserves a wonderful array of Early and Middle Ordovician fossils as well as spectacular erosional features. Dinosaur Provincial Park is one of the 


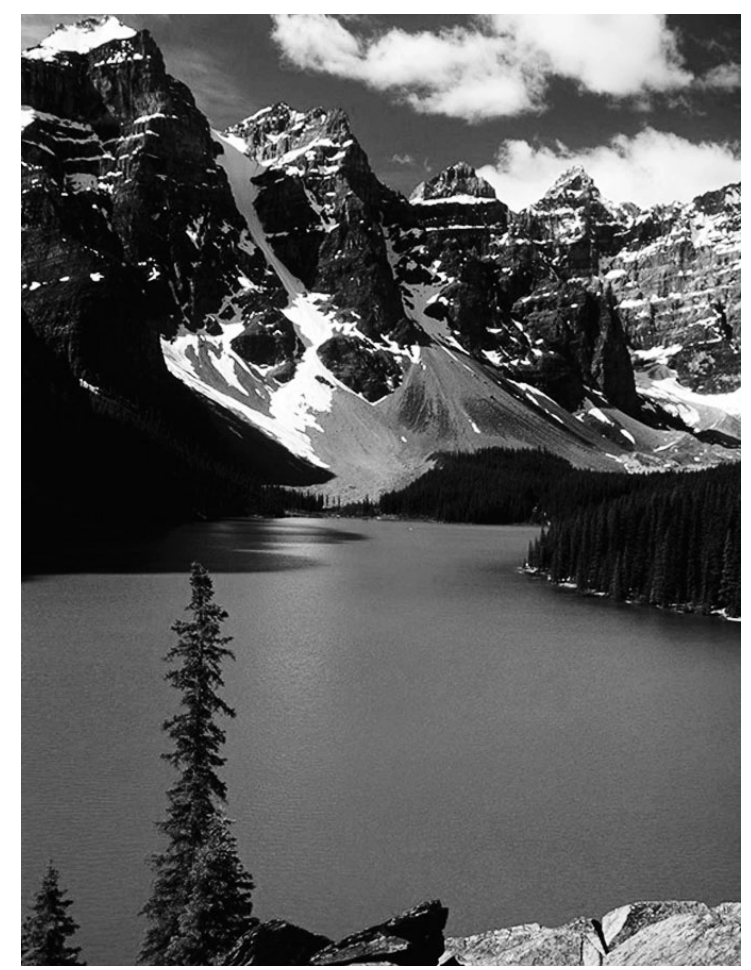

Figure 2 Moraine Lake and part of the Bow Range, Banff National Park, Alberta, Canada (photo courtesy of Parks Canada).

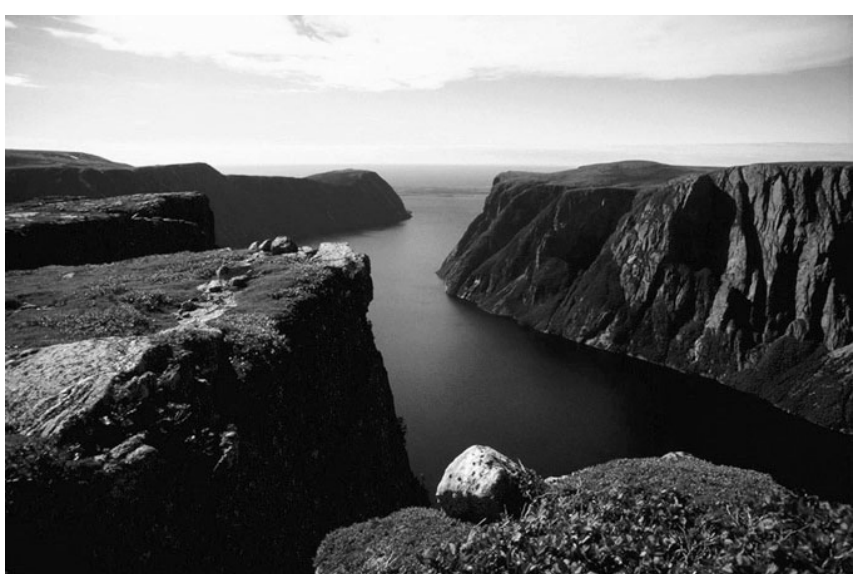

Figure 3 Western Brook Pond Gorge and Long Range Plateau, Gros Morne National Park, western Newfoundland, Canada (photo courtesy of Parks Canada).

world's best Cretaceous dinosaur sites, and many important fossils are known from here (Figure 4).

The long history of parks in North America has given rise to a tradition of family camping holidays that are part recreation and part education. Over the last hundred years millions of North American children have developed their first taste of the natural environment from a visit to a national or provincial park. As a result parks have become major centres of environmental, scientific, and cultural education (Figure 5).

\section{The UNESCO concept of Geoparks}

The concept of a geopark, as outlined in the operational guidelines published by UNESCO in 2002, is to serve the three goals of conserving a healthy environment, educating in the Earth sciences and fostering sustainable, local economic development. The ultimate goal of the Geoparks Program is to provide for a better understanding of geological heritage and wise use of the Earth.

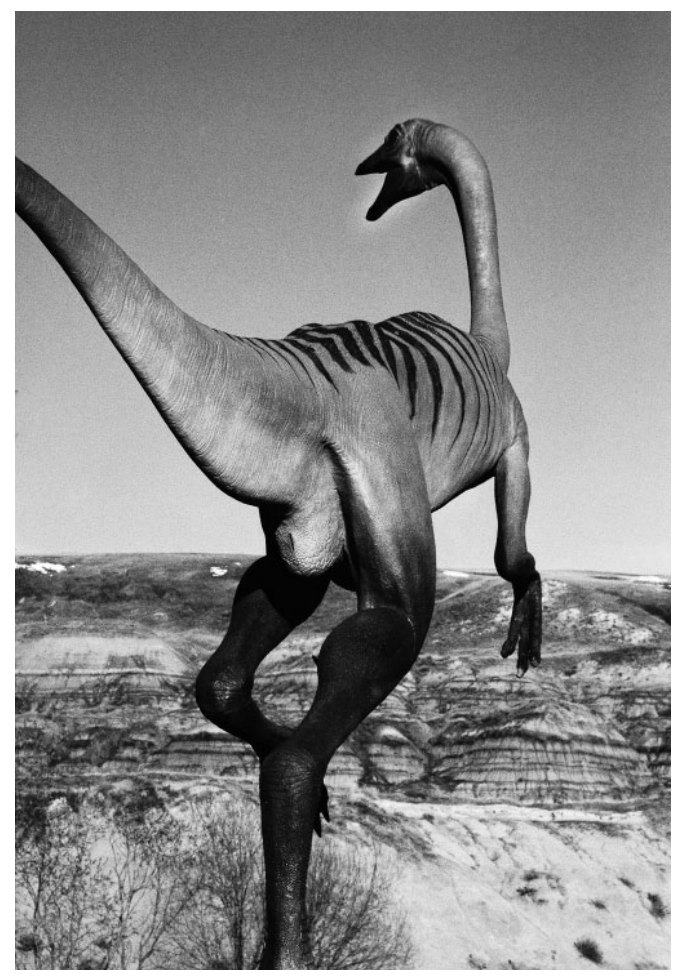

Figure 4 Model of a dinosaur outside the Royal Tyrrell Museum of Palaeontology, Drumheller, Alberta, with the badlands in the background.

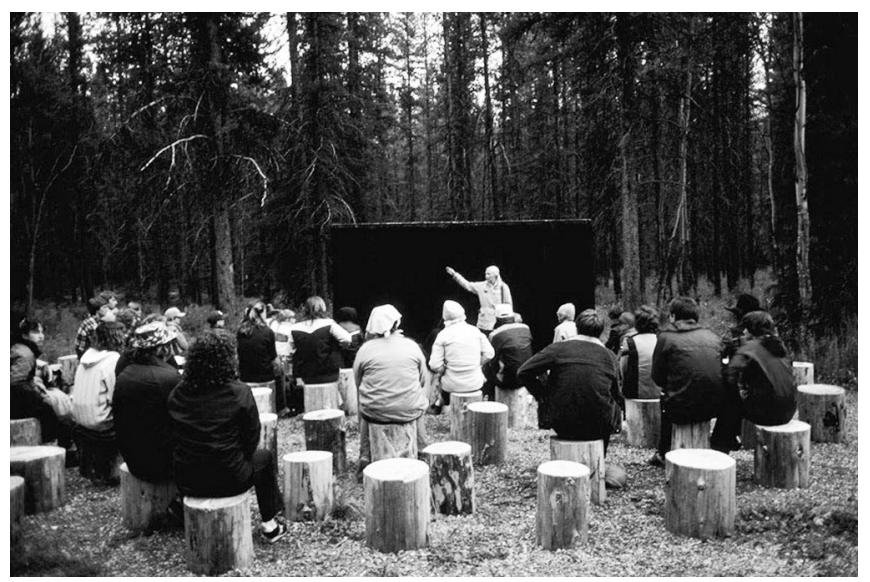

Figure 5 A typical scene of evening interpretation at a Canadian national park (photo courtesy of Parks Canada).

A geopark is a geographically defined area containing one or more geoheritage sites selected on the basis of scientific importance, rarity, scenic quality, or relation to geological history, events and processes. An added impetus of the geopark concept is to connect with local archeological, ecological, historical or cultural values.

One of the great strengths of geoparks is that they are all linked under one international program sponsored by UNESCO. A visitor to one geopark will be made aware of all other such sites in the world, akin to the recognition afforded to World Heritage Sites. Another strength of the geoparks concept is that it fosters socio-economic development in a region. The guidelines stipulate that this development must be culturally and environmentally sustainable, while they encourage local businesses and cottage industries and, ultimately, the creation of new jobs, including geotourism. The intent is to improve living conditions and the rural environment and, in doing so, strengthen the connection of people to their land. Conservation of sites of geological interest is a core value of the geoparks program. Obviously this aspect of geoparks needs to be evalu- 


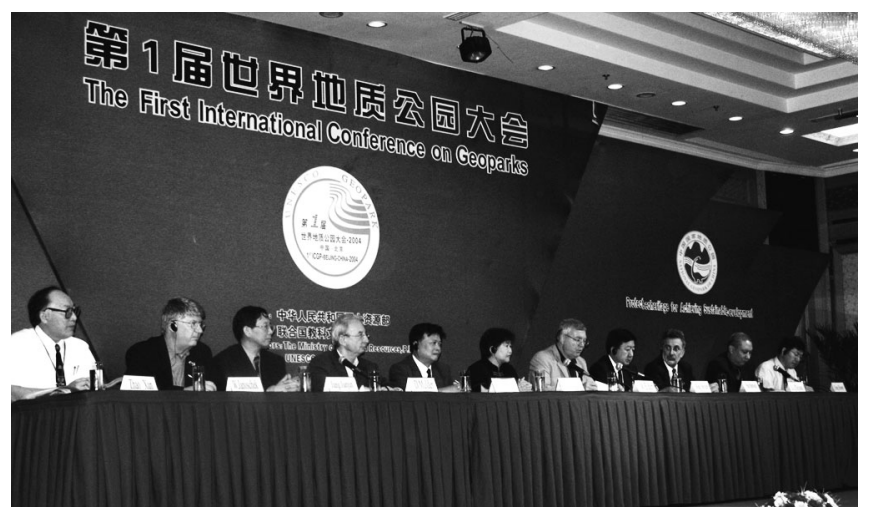

Figure 6 Dignitaries at the First International Conference on Geoparks, Beijing, China, June 2004.

ated in the context of national and regional government regulations and in consultation with an appropriate national or regional geological survey. Once a geopark is established, it is managed by an agency or group that is responsible for the conservation of the area, including any physical maintenance.

A basic tenet of the geoparks program is to provide educational opportunities for visitors. The educational scope is broadly defined and includes not only scientific explanations of geological features but also education on broader environmental issues and sustainable development. A key element of an application for geopark status is the pedagogical program that is planned for the park and the target groups of that pedagogical program.

Perhaps the most interesting aspect of geoparks is that their administration involves a broad cross-section of the community. Public authorities, local organizations, private interests, and research and educational bodies all have a say in the design and running of the park. The intent is to stimulate discussion and encourage partnerships between the different groups involved, thus developing a sense of community and empowering the local population.

The People's Republic of China has been a strong proponent of geoparks, and there are currently more than eighty in the country. Eight of these are designated world geoparks under UNESCO patronage (Jiang, 2004). It was therefore fitting that the first International Conference on Geoparks was held in Beijing (Figure 6). Public promotion of these world geoparks is intense and some parts of China are reaping a benefit in increased tourism from their establishment.

The other main region where geoparks are being developed is Europe. Seventeen geoparks are distributed in Austria, France, Germany, Greece, Ireland, Italy, Spain and the United Kingdom. The concept is also under consideration in other countries including Australia, Egypt, Malaysia, Mexico, Morocco, Saudi Arabia, Slovakia and Sri Lanka (see Zhao et al., 2004). In fact, one of the few regions where geoparks are not yet being considered is North America, probably because of the long history of protection of public lands in the United States and Canada. In the following section we will compare the geopark system with the system of parks that has long existed in North America.

\section{Comparison of park concepts}

Parks in North America have been established to protect the natural environment or historical heritage from development. When Europeans first arrived in North America, they saw almost completely undeveloped and unspoiled lands. Parts of this undeveloped land were initially protected as parks. As development has moved to more remote areas, such as the Canadian Arctic and Alaska, the establishment of new parks has continued. In many other parts of the world, where population density has been much higher over a much longer period of time, little or no land remained undeveloped thus there was no opportunity to protect it. This simple fact is, in essence, the difference between park development in North America and elsewhere.
The availability of undeveloped land for protection means that the philosophy of North American parks is partly different from that of geoparks. Parks in North America are areas of complete protection with only small areas set aside for development. The protection is strong and complete, and any activity to be undertaken in the park is subject to scrutiny and permitting. In this philosophical environment, the socio-economic development that has taken place was a by-product of the process rather than something inherently favoured by it. In some cases, development has reached such an extent that there is now strong debate about allowing it to continue. In Canada in particular, the amount of development that is taking place at the town site of Banff, Alberta, which is part of the Rocky Mountain Parks World Heritage Site, is being vigorously debated (Figure 7). By contrast, sustainable socio-economic development is encouraged in geoparks in Europe and China and is considered in the way the park is developed. This is a highly significant difference and allows development of parks in concert with socio-economic concerns in the region.

A second fundamental philosophical difference is that the entire local community is engaged in the development of a geopark. Local administration, business, educational and research organizations all play a role. When a new national park is established in Canada, people may be moved out of the area because the philosophy is to return the area to its natural state and not to consider human interaction with the land.

A third difference between North American parks and the geoparks system is that all geoparks are interconnected, each providing reference to the others. In North America, parks have separate and different origins, which depend on the level of government that supports them. They range from the better-known national parks, to provincial and state parks, and municipal parks. There are many different categories of parks and recreation areas, and the degree of protection afforded each is different. Some, like national parks, have strong preservation and conservation focuses, whereas others allow limited forestry and oil and gas development, as well as recreation.

Both North American parks and geoparks play similar roles in terms of their mandate to protect geoheritage and to educate the public. Interpretive signs and tours are hallmarks of both kinds of parks (Figure 8).

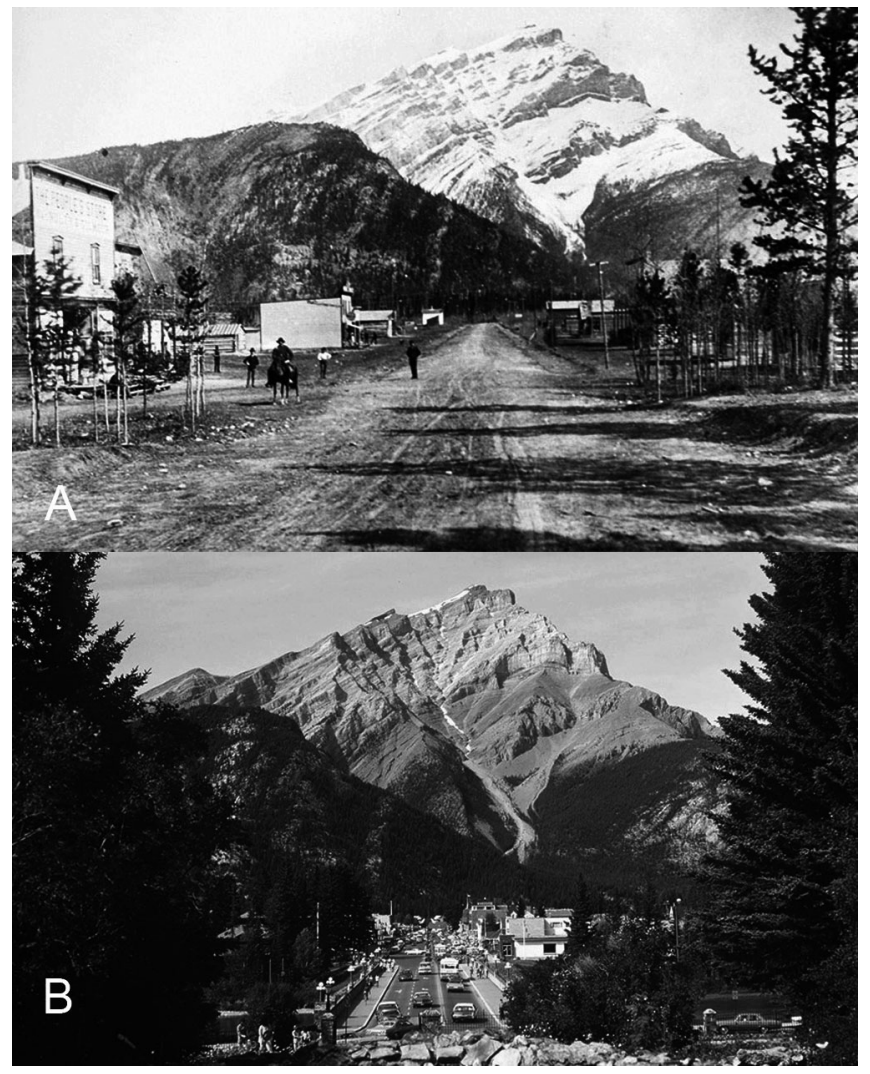

Figure 7 Views of the main street in Banff in 1887 (top) and more recent times (bottom) (photos courtesy of Parks Canada). 


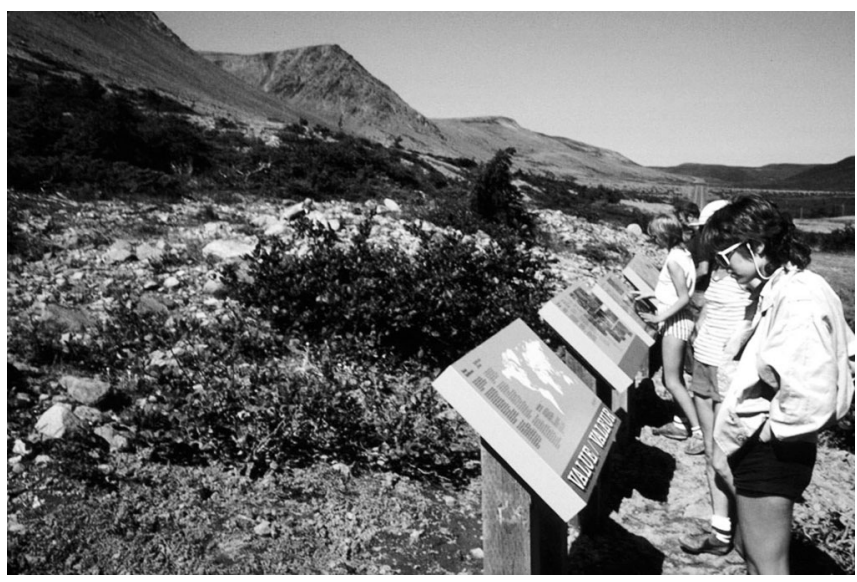

Figure 8 Interpretive signs at the Tablelands in Gros Morne National Park, western Newfoundland, Canada (photo courtesy of Parks Canada).

\section{Scope for Geoparks in North America}

North America is well endowed with parks of all sorts, but we believe there is scope for geoparks in the United States and Canada. Most existing parks in North America are located in areas of exceptional natural beauty or significant historical heritage. There are, however, many other places with significant geoheritage located far from the normal tourist haunts. Many of these areas are economically depressed. The decline of the rural economy in recent years has meant the depopulation of many small towns. Such areas could benefit enormously from the establishment of geoparks. Examples include places with exceptional fossils, rocks or minerals, areas with a rich history of mining or energy development that is now complete, and remote communities in northern regions. Establishment of a geopark could increase tourism to the area and help to reverse a declining economy.

A significant advantage of geoparks over traditional North American parks is that the primary motive for establishing them is an aspect of geoscience. The park thus serves primarily as a vehicle for geoscience education. By contrast, many North American parks that are located in areas of interesting geology focus more on the ecology and biology of the area than on the geology.

A new grassroots geoheritage movement has emerged in Canada with the formation of the Friends of Canadian Geoheritage. This movement originated in the Ottawa area with the OttawaGatineau Geoheritage Project, which aims to preserve irreplaceable geological formations and landforms. Friends of Canadian Geoheritage strive to protect sites by encouraging enforcement and strengthening of applicable laws and by promoting public awareness of sites through brochures, signs and guidebooks. The Canadian geoheritage movement is committed to local involvement in the preservation, protection and promotion of important sites. It thus is well placed to embrace the geoparks concept.

\section{Parks and geoscience education}

Whatever its origin, a park presents an opportunity to educate the public if it contains significant geoheritage. North American parks allow for communicating many geoscience issues to the public. But how much high-quality communication occurs? And what are the messages that are communicated to park visitors? Most park educational programs focus on ecology and biology, and, on average, much less attention is paid to geology. On the other hand, geoparks are dedicated to the interpretation of geology, albeit with recognition of the ecological and cultural values in the area. The average visitor to a North American park has little understanding of earth sciences because it is not widely or consistently taught in schools. Much to the amusement of the rest of the world, we still struggle with the teaching of evolution in many areas.

One of the difficulties in communicating geoscience issues is that geology tends to get lots of negative news. Perhaps a volcanic eruption or earthquake has devastated an area and caused substantial loss of life, or maybe there has been a catastrophic flood, a landslide has blocked an important highway, or an oil spill has polluted the ocean. None of these stories provides a positive image of geology. The challenge is to provide necessary background information to people so that they come to understand Earth processes better. It is important to show that earth processes, like the seasons, affect our everyday life. We need to advise the public that some land is unstable and therefore not a good place to build structures. We should suggest that building homes on floodplains will ultimately have bad consequences. We need to instill in people the notion that we cannot change Earth processes to suit our needs: earthquakes will happen and we need to be prepared. We should also let people know that we sometimes change earth processes to our detriment. For example, efforts to stop erosion at one point on a coast can cause more severe erosion at another place if we are not careful. We need to remind people of the problem of pollution and to advocate respect for the environment.

A second key issue to explain to the public is the degree to which people rely on earth resources in their everyday lives. The lack of understanding of the relationship between well-being and natural resources is particularly acute in developed countries, especially among the inhabitants of large cities. Rural people, who are closer to the land, have a better intuitive understanding of our relationship to resources and the Earth. Ironically, parks are commonly places where resource extraction or other land disturbance is prohibited. This, in itself, leads those with an interest in the environment to develop a negative attitude to resource industries, but the fact is that all humans rely on the extraction of resources. Whether it is coal to power generators, or oil and gas to provide energy for transportation and fabrication of plastics, or mining of metals for construction materials, every human being is using products from the Earth. This has been true from the times of primitive nomadic cultures to the complex technological world of today (Figure 9).

We need to pass on the message that Earth resources are precious and should be used wisely, and to show that they are localized such that natural processes, not human choice, dictate locations of gravel pits, mines and oil wells. We must indicate that Earth's resources are limited and should be conserved and recycled wherever possible. We should state that in many parts of the world Earth resources are too cheap for us to value them properly. For example, car fuel has been so inexpensive in North America that people have bought larger and heavier cars than in the past. Now, with rising fuel prices, people are beginning to understand how much energy they use. And finally we need to make people realize that nothing can be thrown away. We can only store it in a separate place, the landfill.

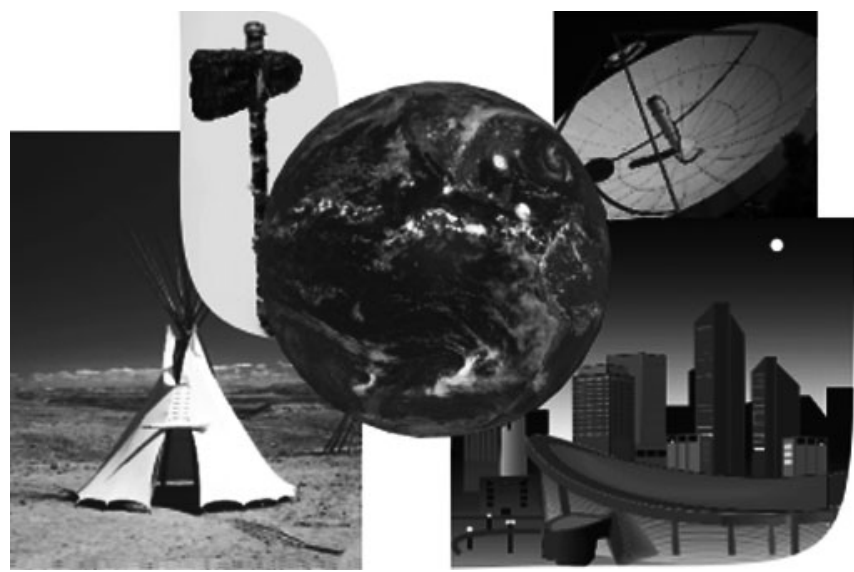

Figure 9 Stylistic representation of how the need for Earth resources has remained constant throughout human civilization. 
A teacher can play the game of "find the resources" with school children, in which the challenge is to find something in the classroom that is not made from a resource that came from the Earth. In this game it is easy to demonstrate that everything in the classroom comes from the Earth. This is the type of activity that should be conducted with families in parks so that they get a better understanding of their reliance on Earth materials and learn to respect all aspects of the issue, from exploration to exploitation to clean-up.

What better place to begin this process of education than at parks of all sorts. Geoparks have an advantage over traditional North American parks in that their philosophy of preservation includes human interaction with the Earth. Indeed, some geoparks, for example the Copper Coast in southeastern Ireland, are based on the historical extraction of minerals from the area.

At least three groups of people can be educated through parks. First, there are the politicians who make decisions on the preservation of park land. It is very important that geoscientists provide information to politicians so that they can make better, more informed decisions. In Canada, we work the legislatures and try to connect with politicians in their electoral districts. In the United States, geoscientists have taken politicians on field trips. Such trips provide an opportunity to cultivate productive working relationships between scientists and decision makers. The second group is the general public, which is the largest group of park visitors and yet perhaps the most difficult to educate. It is difficult to reach everyone in such a diverse group, thus it is probably best to focus on the third group, children, who are, after all, the planet's most important natural resource. Parks are wonderful places to provide hands-on activities for children, providing experiences that they will remember through their adult years. There is a long tradition of park interpreters providing programs for families in North American parks but, sadly, these are much more limited than they used to be. Many park interpreters are formidable musical or dramatic performers that amuse and educate at the same time. Parks are also wonderful locations for teaching teachers, which is perhaps the most cost-effective and least time-consuming way of getting important geoscience messages out to the public. Each teacher who understands something about the Earth can pass that information on to his students. If they are passionate about what they teach, they will leave an indelible mark on the generation under their instruction.

In all the educational activities that take place in parks we must let people know that earth scientists do sophisticated work to locate resources, understand Earth processes and develop plans for the environmentally responsible and sustainable development. Our profession needs more respect on the world stage.

Interpretation of the Earth through parks of all types can result in a number of societal benefits. These include a better informed electorate that is more sympathetic to science, better informed decision-makers, people who live in greater harmony with the Earth and use Earth resources wisely and children that grow up to be more attuned to the Earth, its resources and processes.

\section{References}

Jiang Jianjun (Editor-in-Chief on behalf of the Ministry of Land and Resources), 2004, The World Geoparks of China. Chinese Environmental Publishing House, Beijing, 141 p.

Zhao Xun, Jiang Jianjun, Dong Shuwen, Li Minglu and Zhao Ting, 2004, Proceedings of the First International Conference on Geoparks. Geological Publishing House, Beijing, 468 p.

\section{Web references}

UNESCO World Geopark site, http://www.unesco.org/science/earthsciences/geoparks/geoparks.htm

European Geoparks site, http://www.europeangeoparks.org/
Godfrey Nowlan is a research scientist and geoscience outreach specialist with the Geological Survey of Canada based in Calgary, Alberta. He is an author of more than a hundred scientific publications on Lower Paleozoic stratigraphy, biostratigraphy, regional geology and the paleontology of conodonts and other phosphatic microfossils. He is currently a member of the Subcommission on Ordovician Stratigraphy and Chairman of the IUGS Publications Committee. He is also well known as a strong proponent of geoscience outreach and is currently conducting a major program of outreach in northern Canada.

Peter Bobrowsky obtained his PhD in Geology from the University of Alberta in 1989. He specializes in natural hazards research and works for the Geological Survey of Canada where he is Head of the Canada Landslide Project. His current research includes landslide assessment of Machu Picchu, Peru, landslide hazard mapping applications in Italy and defining methodologies of landslide risk assessment. He has authored/coauthored over 200 publications in his career and is Secretary General of the IUGS.

John J. Clague is Canada Research Chair in Natural Hazard Research at Simon Fraser University and emeritus scientist, Geological Survey of Canada. He has published over 200 papers in a range of earth science disciplines, including glacial geology, geomorphology, stratigraphy, sedimentology, and natural hazards. His other principal professional interest is improving public awareness of earth science by making relevant geocience information available to students, teachers, and the general public. John is a Fellow of the Royal Society of Canada, President of the International Union for Quaternary Research (INQUA), and recent recipient of the Royal Society of Canada's Bancroft Award.
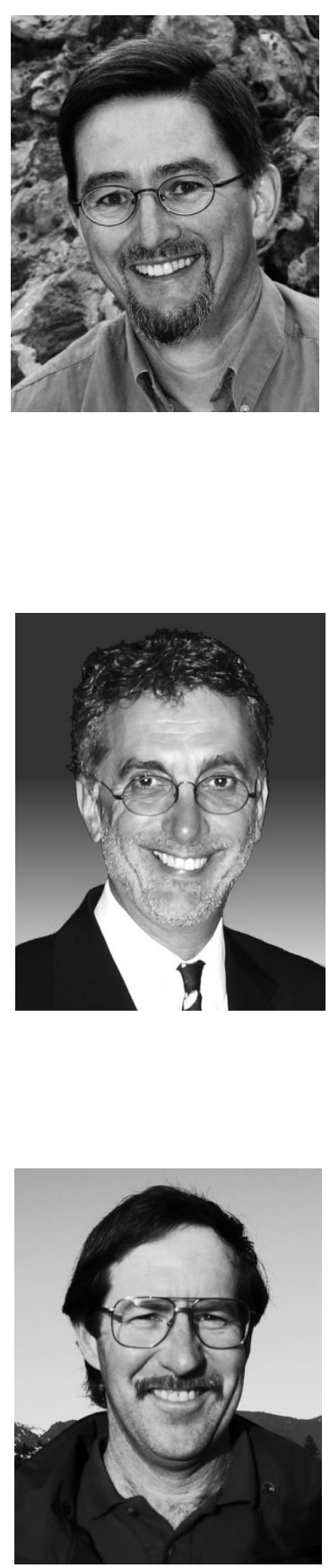